Сочиолошки преглед, год. XLIV (2010), бр. 2, стр. 325-336.

Slobodanka Markov

Aleksandra Izgarjan
UDK: 159.019 .4

Прегледни научни рад

Примљен:

15. 04. 2010.

\title{
PERCEPTION OF THE ENTREPRENEURSHIP OF THE MALE AND FEMALE STUDENTS AT THE UNIVERSITY OF NOVI SAD
}

This paper reports the research findings on entrepreneurial aspirations of male and female students from the University of Novi Sad, which was conducted in 2007/2008. The objective of the research was to examine the impact of social context and entrepreneurship education on entrepreneurial intentions of students. We examined the way students perceive social context for entrepreneurship including the social and economic changes typical for the society in transition. Gender perspective was taken into account as research specifically investigated the ways in which female and male students in particular have been affected by changing social and economic circumstances in Serbia. The results of our research confirmed that gender factor is very influential in determining the level of entrepreneurial aspirations of students, namely male students are much more likely to venture into business sphere than female students. This can largely be explained by the way female students were socialized and made to understand their role in the family and community. Thus, we conclude that patriarchal system coupled with unstable environment in transitional society (high degree of corruption, political instability, and frail legal framework) are key factors which shape female students' indecisiveness to become entrepreneurs.

Key words: entrepreneurial aspirations, gender perspective, student population

The objective of this paper is to report results of the research which investigated the impact of social context and entrepreneurship education on the entrepreneurial intentions of students at the University of Novi Sad. Our hypothesis was that social and economic variables and educational experience, gained during studies, significantly shape the way male and female students perceive entrepreneurship. Empirical research was conducted at the six faculties of the University of Novi Sad in the winter semester of 2007/2008. The questionnaire was filled by 653 students. These students attended faculties and departments which provide good starting point for entrepreneurship (e.g. graphic design, engineering management, tourism and hotel management, veterinary medicine, faculty of economy, mechanical engineering, English language and literature). In the data analysis we used $\chi^{2}$ test of independence and descriptive statistics in the program package Statgraphics, with threshold of $\mathrm{p}=00,05$.

The conceptual framework for the research was created on the basis of the perceptions of the situational factors (Lüthje, Frank, 2003). We have also used career socialization theory (Dyer, 1994), according to which, the decision to start a career is influenced by many social factors including exposure to educational 
Slobodanka Markov, Aleksandra Izgarjan, Perception of Enterepreneurship of ther Male...

experiences such as opportunities to exercise significant responsibilities, start one's own firm and learn from role models. Education influences person's desire to pursue a career in accordance to their learning experiences and affects the perceived desirability of starting a business (Kram, 1983; Shapero \& Sokol, 1982; Peterman \& Kenedy, 2003.) We also relied on the research findings which examined gaps between students' entrepreneurial needs and aspirations and higher education capability (Collins, Hannon and Smith, 2004).

In the first phase of the research, we examined the way students perceive social context for entrepreneurship. We took into account gender perspective and examined how female students in particular have been affected by changing social and economic circumstances in Serbia. We tried to explore the ways the female students were influenced by different aspects of their social location such as patriarchal patterns in Serbian society which often assign dominant position to male members of the family. This is reflected in the entrepreneurial orientations of both male and female students.

As can be seen from the Table 1, male students (52.9 percent) are generally more likely to be willing to start their own business in contrast to female students (37.4 percent). There is approximately the same number of male ( 24.1 percent) and female (22.1 percent) students who have intentions to become entrepreneurs eventually but not immediately after graduation. However, it is important to note that 40.5 percent of female students have never considered starting their own business in contrast to 23.0 percent of male students. This shows a typical pattern in which more male students want to become entrepreneurs and consider entrepreneurship a very likely career option, while female students are reluctant to run a business or have not even thought about it.

Another significant difference between male and female students is in relation to the question whether they would want to start a business on their own or jointly with colleagues, friends or relatives (Table 2). More female respondents prefer to start business jointly with somebody, being part of a team (58.3 percent) compared to 29.8 percent of male students who wish to do so. Majority of male respondents, on the other hand, would prefer to start business on their own (52.9 percent) compared to 37.4 percent of female students. This data shows that female respondents are in general more reluctant to start a new business and especially to start it alone. One possible explanation of such reluctance is the fact that until very recently business ownership in Serbia has been closed to women. Another possible explanation is female students' preference for team work and their desire to minimize the risks involved in starting a business.

It is also significant that many more male students (62.5 percent) expect to inherit the family business in opposition to just 37.5 percent of female students (Table 3) with such expectations. This indicates that the patriarchal pattern of passing down family business to male members of the family, especially sons, is still present in Serbia. This in turn limits entrepreneurial intentions of female students. This can be understood in context of traditional male and female role 
Сочиолошки преглед, год. XLIV (2010), бр. 2, стр. 325-336.

divisions in family. Problems for female students commonly begin after graduation. This is when their desire to realize their ambition to become successful business women may clash with expectations of their community which wants them primarily to fulfill the role of good wives and mothers. Answers of the respondents in our research who are from smaller towns and less developed regions of Serbia clearly reflect such opinion, that is, that women are seen as belonging only to domestic sphere and that their primary role is to take care of their children and the household. Therefore, most female students who have such background commonly repress their entrepreneurial intentions because they do not want to be perceived negatively by the members of their community. (Markov, 2008). As testified by some participants in our research:

'I think discrimination is real. People think that business women are not capable of doing a job properly the way businessmen are. That means that the community does not trust women as much as it trusts men.'

'In the past men were always the ones who were working and making money for the family and women stayed at home. Mostly, it is still like this.'

'I have female friends who believe that we women should only sit at home and give birth to children.'

Yet another significant difference between female and male respondents in the research is apparent in their answers to the question whether they would start a business out of necessity or because they find having own business desirable. 67.9 percent of female respondents expect to start their own business predominantly out of necessity in comparison to 32.1 percent of males who feel this way (Table 4). This implies that female respondents turn to entrepreneurship not because they value it in itself but predominantly because they do not see another alternative in unfavorable economic climate in Serbia. This means that economic necessity (push factor) such as a very high rate of unemployment in Serbia is the main determinant which influences female students to venture into business sphere.

Gender differences are apparent in all other areas of investigation, including perceptions of advantages and disadvantages in starting a business, desired timing of starting a business and access to already existing business networks. For example, Table 5 shows the estimated time the students plan for business start-ups. More male students (33.6 percent) want to start their business one or two years after graduation in comparison to the smaller number of female students (23.8 percent). This again points to higher confidence of male students. Also more male students (52.8 percent) would start business three to five years after graduation in comparison to female students (47.5 percent). On the other hand, twice as many female students ( 28.7 percent) than male students (13.6 percent) would want to wait five or more years before starting their own business. This reflects female students' reluctance to take risks at the volatile business market.

Male students, on the other hand, tend to perceive themselves and associated risks with starting a business differently. When asked what their advantages in 
Slobodanka Markov, Aleksandra Izgarjan, Perception of Enterepreneurship of ther Male...

starting a business would be, 60.8 percent of male students answered that one of their advantages is willingness to take risks in comparison to just 39.2 percent of female students (Table 6). Male students are also more motivated than female students by the potential financial gain ( 57.7 percent to 42.3 percent). Interestingly, more female students than male students see as their advantage the ability to handle money (62.2 percent to 37.8 percent). This can be ascribed to the fact in Serbian society that women are generally in charge of the family budget; during several serious economic crises in the past it was women who had to become experts in making ends meet. Additional positive qualities that female students consider to be their assets are reliability and punctuality (55.8 percent). Less male respondents (44.2 percent) perceive these qualities as their main assets.

When asked about their weak points (Table 7), more female than male students see lack of the initial capital as an impediment to start-ups (55.8 percent of female students compared to 44.2 percent of male students). Similarly, both female students (52.9 percent) and male students (47.1 percent) perceive lack of work experience and knowledge of how businesses are run as their weakness preventing them to become entrepreneurs. This is to be expected in the society in transition like Serbia where there is a high degree of unemployment and thus chances of getting a job or even an internship are rather small.

Our research also indicates that female students do not have entrepreneurial intentions because they do not have an access to existing business networks (Table 8). More female students (35.1 percent) do not know any entrepreneurs in opposition to male students ( 24.0 percent). Male students seem to know more entrepreneurs who have become successful in illegal or semi legal ways (43.0 percent) than female students (35.1 percent). This indicates that considerable number of male and female students is aware that in Serbian transitional society there are possibilities to succeed in business using illegal or semi legal means. It is interesting that this seems to have less of a negative impact on the male students who are still willing to take their chances with start-ups as can be seen from their answers. However, female students are less willing to engage in entrepreneurship in such circumstances since this is a repelling factor for them. Thus, we can say that patriarchal system and instable and chaotic environment in transitional society (high degree of corruption, political instability, and frail legal framework) are key factors which shape women's indecisiveness to become entrepreneurs.

Furthermore, female students tend to view economic and political situation in Serbia much more negatively than male students and this also inhibits them and discourages them to venture into business sphere. As can be seen from the Table 9, when asked what they perceive as obstacles to development of entrepreneurship in Serbia, female students clearly show tendency to see things more pessimistically. Respondents stated that they see high taxes as a problem (67.6 percent of female compared to 32.4 percent of male students), next are slow economic recovery (65 percent of female compared to 35 percent of male students), high degree of corruption (62.2 percent of female compared to 37.8 percent of male students), 
Сочиолошки преглед, год. XLIV (2010), бр. 2, стр. 325-336.

unstable political situation (62.6 percent of female compared to 37.4 percent of male students), existence of grey market (58.2 percent of female compared to 41.8 percent of male students), and absence of bank loans (56.7 percent of female compared to 43.3 percent of male students). The only two areas where male and female students show similar degree of pessimism are regarding bad legislation (51.7 percent of male compared to 48.3 percent of female students) and unfavorable legal climate (51.3 percent of male compared to 48.7 percent of female students). Other researches on female entrepreneurs in Serbia confirm these data (Markov/Mirkov 2006, Markov/Stanković, 2008).

The respondents' answers to the question regarding their estimation of social context for development of business also confirm the above mentioned postulates (Table 10). Small number of students estimate social context in Serbia today as favorable for private business (15.4 percent of male and 16.0 percent of female students) which is to be expected. Higher number of male than female students think that the conditions are unfavorable (53.0 percent to 40.7 percent). Still that seems to have less influence on male respondents' aspirations in becoming entrepreneurs as could be seen from previously mentioned results. Precisely because of such similar results from other researches (Markov/Mirkov 2006), we decided to include gender factor in our analysis. It is evident here in which way social environment plays a decisive role in shaping entrepreneurial intentions of students: female students have commonly been socialized to be less competitive and more oriented toward corporative sectors where there is more security. Shapero's model of the entrepreneurial event (Shapero, 1975, 1982) hypothesizes that the intent to start a business derives from perceptions of both desirability and feasibility and from a propensity to act upon opportunities. Therefore it may be said that since female students do not show intentions to start a business, it is very unlikely that they will do so.

Table 11 shows fields in which the students intend to start their business. 69.9 percent of female students plan to do business in the field for which they have been educated at the university in comparison to 60.1 percent of male students. This indicates that both male and female students feel more secure in the fields for which they were educated, but still more female students express this attitude. Female students are less inclined to take risks in new fields for which they were not prepared. 11.9 percent of male students are willing to start a business in a new field in opposition to 5.2 percent of female students. Similarly, 10.5 percent of male students would start a business in a new field which yields bigger profit in comparison to 5.8 percent of female students. We can assume that same reasons lie behind reluctance of female students to enter fields which bring more profit but for which they are not educated. This shows their lack of self confidence, as well as indecisiveness. Same factors are responsible for the fact that twice as many female students (14.4 percent) than male (6.3 percent) have no precise opinion in which field they would start their business. 
Slobodanka Markov, Aleksandra Izgarjan, Perception of Enterepreneurship of ther Male...

We also examined the way students perceive their future and more specifically whether they plan to start their business in the country or continue education in country or abroad (Table 12). Approximately the same number of male and female students wants to find employment in Serbia (40.7 percent of male students and 43.9 percent of female students). At the same time, more female (10.6 percent) than male students ( 4.7 percent) plan to continue their studies. This confirms our earlier findings that male students are bolder and more eager to test their entrepreneurial skills immediately after graduation, while female students come across as more insecure of their knowledge so instead of starting their business they opt to continue studying.

The last part of the questionnaire explored students' perception of entrepreneurial education and activity at the University of Novi Sad. We asked students who stated that they want to venture into business sphere whether they think that the knowledge they have gained at the university is sufficient for starting of their own business. The results can be seen in Table 13. It is remarkable that only 8.4 percent of male students and 4.6 percent of female students think that the knowledge they gained at the university is completely sufficient. 42.0 percent of males and 45.4 percent of female students consider their education 'mostly sufficient'. This leaves a high number of students who think that their knowledge is not sufficient enough for business ventures (46.1 percent of male students and 42.8 of female students).

Our findings reveal overall dissatisfaction of the students with the quality of educational programs at the University of Novi Sad. That is, they believe that education is too theoretical in nature and not easily applicable in the sphere of entrepreneurship. As stated by participants in our research:

'We are taught too many outdated theories. We need knowledge about new theoretical approaches and practice in terms of their application.'

'We need more subjects and specializations in management subjects that are based on natural sciences. We do have knowledge of many technical details but we do not know how to properly utilize this knowledge.'

'I think students in general know very little about entrepreneurship and about many ways in which one's own business could be started. This should be a first step towards being informed and eventually initiating a business.'

We also asked them in which fields of entrepreneurship they gained knowledge and it was startling to discover that 29.4 percent of both male and female students were not offered any courses in entrepreneurship. Equally surprising was to find out that only 1.5 percent of all students learned anything about new fields of business such as financial management, negotiation skills, and communication skills. Both male and female students (50.0 percent of female compared to 50.3 percent of male students) think that come changes have been introduced at the university, but that those changes are not sufficient (Table 14). 27.5 percent of female students and 23.7 percent of male students view university climate as static 
Сочиолошки преглед, год. XLIV (2010), бр. 2, стр. 325-336.

and without any innovations. Only 15.0 percent of female students and 16.8 percent of male students regard the atmosphere at the university as very dynamic and full of innovations.

In general, students think that their university is not working enough on the education and training of students for entrepreneurship. The results (Table 15) show that the significant number of students perceive the whole atmosphere at the University of Novi Sad as insufficiently supportive of formation and broadening of entrepreneurial knowledge, ideas and behavior. When asked what should be done at the university to enable students to start their own business, 22.1 percent of male students and 21.1 percent of female students said that courses in entrepreneurship should be introduced, 24.7 percent of male and 23.0 percent of female students suggested that space should be provided for entrepreneurial projects of students. Lastly, 20.2 percent of male and 27.1 percent of female students think that the university should create conditions within departments for student start-ups and projects.

On the basis of the gathered data, we can conclude that educational processes at the University of Novi Sad at the time when this research was conducted were not geared towards preparation of students for challenges of entrepreneurship. One characteristic finding is that students estimate that faculties "barely" enable them to develop entrepreneurial behavior and entrepreneurial projects. It seems that seen as a whole, introduction of changes, including entrepreneurial teaching and practice, is much slower than the students expect and real needs of the society demand. Around half of the students who did the questionnaire think that there are some changes, but not sufficiently enough, while quarter of the students experience university environment as closed, without any innovations. The students see their participation in conception and realization of entrepreneurial projects as very limited in scope. Logically, when proposing measures that would enable them to manage their own business, students mention in the first place provision of conditions for entrepreneurial projects, inclusion of students in project within departments, introduction of elective courses in entrepreneurship for all students at the University. It is also significant that previous research showed that students estimate that some of professors and mentors encourage them to think and conceive entrepreneurial ideas and projects (Markov/Stankovic, 2008). This indicates that there are some professors who are dedicated to introduction of entrepreneurial practices and who can serve as role models not just for students but also for their colleagues.

The results of our analysis point to the conclusion that the University of Novi Sad lacks not only tradition of entrepreneurial practices, but also does not offer courses on the basis of which such practices would be initiated and encouraged. It is clear that there is a need for systematic measures of the University to develop entrepreneurial intentions. This does not refer only to the introduction of entrepreneurial courses, but also to the implementation of measures which would 
Slobodanka Markov, Aleksandra Izgarjan, Perception of Enterepreneurship of ther Male...

foster creativity and innovativeness of all participants at the university. This would in turn enhance entrepreneurial culture and spirit among students.

Unfavorable university climate and lack of entrepreneurial education is contrary to the strategy of Serbian government to support development of small and medium enterprises which are seen as crucial factors for economic development. People should be therefore encouraged to start businesses in order to solve the problem of unemployment in the transitional society. This especially pertains to students at the university who present younger portion of Serbian working force capable of innovation in the entrepreneurial sector. Further measures are required regarding to motivating female students to venture into the business spheres and engage in entrepreneurial projects. As far as encouragement of female students to venture into business sphere, there some measures have already been taken, such as those introduced by the government of the Province of Vojvodina to give favorable bank loans to first start ups for women. However, that is not enough. It is our opinion that the university and local communities should organize courses in empowerment of female students and invite successful Serbian business women to participate so that female students would get acquainted with them and they could serve as positive role models to them.

The major findings of our research are the data about the number of students with entrepreneurial intentions since they were not previously available either to Serbian or local governments. Now, they can be aware of the factors influencing young people's intentions to contribute to the entrepreneurial sphere and the role both entrepreneurial education and the overall social context have on them. Our intention was also to initiate the discussion within the university and in wider public sector about the need to encourage and educate students to perceive their potential as entrepreneurs. We hope that the University of Novi Sad will be able to initiate and implement some of the measures proposed above.

\section{Appendix}

Table 1. Question: Do you want to start your own business after graduation: a) yes, b) yes but not after graduation and c) I have never considered starting my own business

\begin{tabular}{|l|l|l|}
\hline & Male students & Female students \\
\hline a & $52.92 \%$ & $37.37 \%$ \\
\hline b & $24.12 \%$ & $22.11 \%$ \\
\hline c & $22.96 \%$ & $40.53 \%$ \\
\hline
\end{tabular}

Table 2. Question: Do you want to start business: a) on your own or b) as part of a team?

\begin{tabular}{|l|l|l|}
\hline & Male students & Female students \\
\hline & $52.92 \%$ & $37.37 \%$ \\
\hline $\mathrm{b}$ & $29.80 \%$ & $58.28 \%$ \\
\hline
\end{tabular}


Сочиолошки преглед, год. XLIV (2010), бр. 2, стр. 325-336.

Table 3. Question: Do you plan to inherit family business?

\begin{tabular}{|l|l|}
\hline Male students & Female students \\
\hline $62.50 \%$ & $37.50 \%$ \\
\hline
\end{tabular}

Table 4. Question: Do you have to start your own business out of necessity?

\begin{tabular}{|l|l|}
\hline Male students & Female students \\
\hline $32.14 \%$ & $67.86 \%$ \\
\hline
\end{tabular}

Table 5. Question: Do you plan to start your own business in

a) 1-2 years after graduation, b) 3-5 years after graduation,

c) 5 or more years after graduation?

\begin{tabular}{|l|l|l|}
\hline & Male students & Female students \\
\hline a & $33.57 \%$ & $67.86 \%$ \\
\hline b & $52.86 \%$ & $47.55 \%$ \\
\hline c & $13.57 \%$ & $28.26 \%$ \\
\hline
\end{tabular}

Table 6. Question: What do you think your advantages in starting a business are? a) ability to handle money, b) willingness to take risks, c) desire to have financial gain and d) reliability and punctuality.

\begin{tabular}{|l|l|l|}
\hline & Male students & Female students \\
\hline $\mathrm{a}$ & $37.78 \% \%$ & $62.22 \%$ \\
\hline $\mathrm{b}$ & $60.81 \%$ & $39.19 \%$ \\
\hline $\mathrm{c}$ & $57.69 \%$ & $42.31 \%$ \\
\hline $\mathrm{d}$ & $44.19 \%$ & $55.81 \%$ \\
\hline
\end{tabular}

Table 7. Question: What do you think your weak points in starting your business would be? a) lack of initial capital and b) insufficient working experience and sectoral knowledge.

\begin{tabular}{|l|l|l|}
\hline & Male students & Female students \\
\hline $\mathrm{a}$ & $44.17 \%$ & $55.83 \%$ \\
\hline $\mathrm{b}$ & $47.13 \%$ & $52.87 \%$ \\
\hline
\end{tabular}

Table 8. Question: Do you know any entrepreneurs? a) no and b) yes and I respect them and c) yes but they gained capital in illegal ways

\begin{tabular}{|l|l|l|}
\hline & Male students & Female students \\
\hline a & $23.08 \% \%$ & $35.06 \%$ \\
\hline b & $32.96 \%$ & $20.08 \%$ \\
\hline c & $42.69 \%$ & $35.07 \%$ \\
\hline
\end{tabular}


Slobodanka Markov, Aleksandra Izgarjan, Perception of Enterepreneurship of ther Male...

Table 9. What do you perceive as obstacles in development of your business: a) high taxes, b) slow recovery of economy, c) high degree of corruption, d) unstable political situation,

e) existence of gray market, f) absence of bank loans, g) bad legislation and h) unfavourable legal climate?

\begin{tabular}{|l|l|l|}
\hline & Male students & Female students \\
\hline a & $32.39 \%$ & $67.61 \%$ \\
\hline b & $35.00 \%$ & $65.00 \%$ \\
\hline c & $37.83 \%$ & $62.17 \%$ \\
\hline d & $37.36 \%$ & $62.64 \%$ \\
\hline e & $41.76 \%$ & $58.24 \%$ \\
\hline f & $43.31 \%$ & $56.69 \%$ \\
\hline g & $51.67 \%$ & $48.33 \%$ \\
\hline h & $51.30 \%$ & $48.70 \%$ \\
\hline
\end{tabular}

Table 10. Question: What is your estimation of social context for development of business in Serbia? A) favourable and b) unfavourable

\begin{tabular}{|l|l|l|}
\hline & Male students & Female students \\
\hline $\mathrm{a}$ & $15.44 \%$ & $15.98 \%$ \\
\hline $\mathrm{b}$ & $52.90 \%$ & $40.72 \%$ \\
\hline
\end{tabular}

Table 11. In which field of you intend to start your business: a) field in which I have been education, b) new field, c) new field which yields bigger profit and d) I have no opinion.

\begin{tabular}{|l|l|l|}
\hline & Male students & Female students \\
\hline a & $60.14 \%$ & $69.93 \%$ \\
\hline b & $11.89 \%$ & $5.23 \%$ \\
\hline c & $10.49 \%$ & $5.77 \%$ \\
\hline d & $6.29 \%$ & $14.38 \%$ \\
\hline
\end{tabular}

Table 12. Question: After graduation, do you want to a) start working or b) continue studies in Serbia or abroad?

\begin{tabular}{|l|l|l|}
\hline & Male students & Female students \\
\hline a & $40.71 \%$ & $43.93 \%$ \\
\hline b & $4.74 \%$ & $10.59 \%$ \\
\hline
\end{tabular}

Table 13. Question: Do you think that knowledge you gained at the University of Novi Sad is sufficient for starting your business: a) yes, completely sufficient, b) yes, mostly sufficient and c) no, not sufficient enough?

\begin{tabular}{|l|l|l|}
\hline & Male students & Female students \\
\hline $\mathrm{a}$ & $8.39 \%$ & $4.61 \%$ \\
\hline $\mathrm{b}$ & $41.96 \%$ & $45.40 \%$ \\
\hline $\mathrm{c}$ & $46.15 \%$ & $42.76 \%$ \\
\hline
\end{tabular}


Сочиолошки преглед, год. XLIV (2010), бр. 2, стр. 325-336.

Table 14. Question: How do you perceive entrepreneurial climate at the University of Novi Sad? A) dynamic and innovative, b) some changes have been made but that is not enough, c) static.

\begin{tabular}{|l|l|l|}
\hline & Male students & Female students \\
\hline a & $16.79 \%$ & $15.03 \%$ \\
\hline b & $50.26 \%$ & $50.00 \%$ \\
\hline c & $23.66 \%$ & $27.46 \%$ \\
\hline
\end{tabular}

Table 15. What should be done at the University of Novi Sad to prepare students to start their companies: a) courses in entrepreneurship should be introduced, b) university should provide space for entrepreneurial projects and c) university should create conditions within departments for projects of students.

\begin{tabular}{|l|l|l|}
\hline & Male students & Female students \\
\hline a & $22.14 \%$ & $21.13 \%$ \\
\hline b & $24.70 \%$ & $23.03 \%$ \\
\hline c & $20.17 \%$ & $27.15 \%$ \\
\hline
\end{tabular}

\section{REFERENCES:}

Collins L. and Hannon P and Smith A. (2004). "Enacting entrepreneurial intent: the gaps between student needs and higher education capability". Education + Training, Vol. 46, No 8/9, , pp. $454-463$.

Dyer, G. (1994). Toward a Theory of Entrepreneurial Careers. Entrepreneurship Theory and Practice Vol. 19, Issue 2: 7-21

Galloway L. and W. Brown (2002). Entrepreneurship Education at University: a Driver in the Creation of high growth firms? Education + Training Vol. 44, No. 8/9. p. $398-$ 405.

Lüthje, Ch., Franke, N. (2003). 'The Making of an Entrepreneur': Testing a Model of Entrepreneurial Intent among Engineering Students at IMT'. R\&D Management Volume 33. p. 135 - 147.

Марков,С., Мирков, С. (2006). Предузетничке тежње студената у Војводини. У: М. Трипковић (прир). Социјални капитал и друитвена интегращија, Нови Сад: Филозофски факултет у Новом Саду, стр. 433 - 444.

Марков, С., Станковић Ф. (2008). Универзитетско окружење и предузетничке тежње студената. У: Марков, С., Станковић, Ф. (прир). Универзитет и предузетништво, Нови Сад: Универзитет у Новом Саду, стр. 73 - 113.

Peterman,E. N., Kennedy, J. (2003). Enterprise Education: Influencing Students' Perceptions of Entrepreneurship. Entrepreneurship Theory and Practice Vol. 28, Issue 2:129-144. 
Slobodanka Markov, Aleksandra Izgarjan, Perception of Enterepreneurship of ther Male...

Слободанка Марков

Универзитет у Новом Саду

Cаже $\mathrm{ma \kappa}$

Природно-математички факултет

\author{
Александра Изгарјан \\ Универзитет у Новом Саду \\ Филозофски факултет
}

\title{
ПЕРЦЕПЦИЈА ПРЕДУЗЕТНИШТВА КОД СТУДЕНТКИЬА И СТУДЕНАТА УНИВЕРЗИТЕТА У НОВОМ САДУ
}

Циљ овог рада био је да се анализирају контекстуални фактори и предузетничко образовање који утичу на предузетничке аспирације студената на Универзитету у Новом Саду. Испитали смо начине на које студенти перципирају друштвени контекст за предузетништво будући да је истраживање спроведено у друштву у процесу транзиције. Нарочито је у обзир узета родна перспектива и начин на који друштвене и економске околности у Србији посебно утичу на студенткиње. Резултати нашег истраживања јасно показују да родни фактор игра велику улогу у одређивању нивоа предузетничких аспирација студената. Иако и студенти и студенткиње на сличан начин перципирају друштвено и образовно окружење, много је већа вероватноћа да ће се студенти, а не студенткиње, отиснути у предузетничку сферу. Ово може у великој мери да се објасни начином на који су студенткиње социјализоване и одређеним улогама које женама бивају наметнуте у породици и друштву. Стога можемо рећи да су патријархални систем и нестабилно окружење у транзиционом друштву (високи степен корупције, политичка нестабилност и крхки правни оквир) главни фактори који утичу на неодлучност жена да постану предузетнице. пулација

Кључне речи: предузетничке аспирације, родна перспектива, студентска по- 